E. Somm - P. Cettour-Rose - C. Asensio - A. Charollais M. Klein - C. Theander-Carrillo - C. E. Juge-Aubry • J. -M. Dayer - M. J. H. Nicklin - P. Meda ·

F. Rohner-Jeanrenaud · C. A. Meier

\title{
Interleukin-1 receptor antagonist is upregulated during diet-induced obesity and regulates insulin sensitivity in rodents
}

Received: 30 May 2005 / Accepted: 24 July 2005 / Published online: 30 December 2005

(C) Springer-Verlag 2005

\begin{abstract}
Aims/hypothesis: The IL-1 receptor antagonist (IL-1Ra) is an anti-inflammatory cytokine known to antagonise the actions of IL- 1 . We have previously shown that IL-1Ra is markedly upregulated in the serum of obese patients, is correlated with BMI and insulin resistance, and is overexpressed in the white adipose tissue (WAT) of obese humans. The aim of this study was to examine the role of IL-1Ra in the regulation of glucose homeostasis in rodents. Methods: We assessed the expression of genes related to IL-1 signalling in the WAT of mice fed a high-fat diet, as well as the effect of Il1rn (the gene for IL-1Ra) deletion and treatment with IL-1Ra on glucose homeostasis in rodents. Results: We show that the expression of Illrn and the gene
\end{abstract}

E. Somm · C. E. Juge-Aubry · C. A. Meier $(\bowtie)$ Endocrine Unit, Department of Internal Medicine, University Hospital and Department of Cellular Physiology and Metabolism, University Medical Centre,

24 rue Micheli-du-Crest,

CH-1211 Geneva 14, Switzerland

e-mail: Christoph.Meier@medecine.unige.ch

Tel.: +41-22-3729192

Fax: $+41-22-3729330$

P. Cettour-Rose $\cdot$ C. Asensio $\cdot$ M. Klein $\cdot$ C. Theander-Carrillo $\cdot$ F. Rohner-Jeanrenaud

Laboratory of Metabolism, Department of Internal Medicine, University Hospital and Department of Cellular Physiology and Metabolism, University Medical Centre,

Geneva, Switzerland

A. Charollais · P. Meda

Department of Cellular Physiology and Metabolism, University Medical Centre,

Geneva, Switzerland

J. -M. Dayer

Division of Immunology and Allergology,

Department of Internal Medicine, University Hospital,

Geneva, Switzerland

M. J. H. Nicklin

Division of Genomic Medicine, University of Sheffield, Royal Hallamshire Hospital,

Sheffield, UK encoding the inhibitory type II IL-1 receptor was upregulated in diet-induced obesity. The blood insulin:glucose ratio was significantly lower in $I l 1 \mathrm{rn}^{-/}$animals, which is compatible with an increased sensitivity to insulin, reinforced by the fact that the insulin content and pancreatic islet morphology of $I l 1 \mathrm{rn}^{-1}$ animals were normal. In contrast, the administration of IL-1Ra to normal rats for 5 days led to a decrease in the whole-body glucose disposal due to a selective decrease in muscle-specific glucose uptake. Conclusions/interpretation: The expression of genes encoding inhibitors of IL-1 signalling is upregulated in the WAT of mice with diet-induced obesity, and IL-1Ra reduces insulin sensitivity in rats through a muscle-specific decrease in glucose uptake. These results suggest that the markedly increased levels of IL-1Ra in human obesity might contribute to the development of insulin resistance.

Keywords Cytokines · High-fat diet · IL-1 · IL-1Ra · Insulin resistance $\cdot$ Interleukin-1 Interleukin-1 receptor antagonist · Obesity

Abbreviations IL-1Ra: IL-1 receptor antagonist · IL-1RI: IL-1 receptor type I - IL-1RII: IL-1 receptor type II $\mathrm{Ra}$ : rate of glucose appearance $\cdot \mathrm{Rd}$ : rate of glucose disappearance $\cdot$ rhIL-1Ra: recombinant human IL-1 receptor antagonist - WAT: white adipose tissue · WATe: epididymal WAT

\section{Introduction}

Adipose tissue is an important source of cytokines and related peptides, regulating body weight homeostasis and insulin sensitivity. Increased production of TNF- $\alpha$ has been detected in the white adipose tissue (WAT) of different rodent models of genetic obesity and it has been speculated that TNF- $\alpha$ contributes to the development of insulin resistance [1]. Clinical studies have also demonstrated the overexpression of $\operatorname{Tnf}$ mRNA in different WAT depots of obese humans, as well as a positive correlation between $\operatorname{Tnf}$ 
expression and hyperinsulinaemia [2, 3], in spite of normal circulating serum TNF- $\alpha$ levels $[4,5]$. IL- 6 has also been shown to be produced by human omental and subcutaneous adipose tissue [6,7], with serum levels positively correlated with BMI [8]. However, although serum levels of IL-6 are slightly elevated in obese patients $[9,10]$, they are not increased beyond the upper limit of the physiological range. We have recently demonstrated that levels of IL-1 receptor antagonist (IL-1Ra) are nearly seven times higher in sera from obese humans [11] and that WAT contributes to the production of this cytokine [12]. We have also shown that this cytokine is overexpressed in the WAT of leptin-deficient $o b / o b$ mice, as it is in the subcutaneous adipose tissue of obese patients [12].

IL-1Ra antagonises the two proinflammatory cytokines IL- $1 \alpha$ and IL- $1 \beta$ by inhibiting their binding to the functional type I IL-1 receptor (IL-1RI) [13]. The type II IL-1 receptor (IL-1RII) acts as a decoy receptor, inhibiting IL-1 signalling [14]. To date, the relationship between obesity and the molecules related to IL-1 signalling has not been examined. Moreover, while the anti-inflammatory role of IL-1Ra is well established, the metabolic relevance of increased serum levels of IL-1Ra observed in human obesity remains speculative, although several lines of evidence suggest that IL-1Ra favours obesity by antagonising the anorexic [11, 15], anti-adipogenic [16, 17] and insulinsensitising effects of IL-1 [18]. Therefore, the aim of this study was to examine the effect of diet-induced obesity in mice on the expression of the genes for various components of the IL-1 signalling pathway in WAT, such as IL-1Ra, IL-1 $\beta$, IL-1RI and IL-1RII. Since IL-1Ra serum levels in humans are more strongly correlated with insulin resistance than BMI [11], we also assessed the role of IL-1Ra as a regulator of insulin sensitivity by using Illrn (formerly known as $I L-1 r a)$ knockout mice and by administrating IL-1Ra to normal rats.

\section{Materials and methods}

Animals All experimental protocols were approved by the Cantonal Veterinary Office (Geneva, Switzerland). Tenweek-old $\mathrm{C} 57 \mathrm{BL} / 6 \mathrm{~J}$ male mice, weighing approximately $25 \mathrm{~g}$, were obtained from the Janvier Breeding Centre (Le Genest-Saint-Isle, France) and housed at room temperature $\left(22^{\circ} \mathrm{C}\right)$, with a 12 -h light-dark cycle and free access to water and food. After 2 weeks of acclimatisation, mice were housed individually and provided with either a standard chow diet $(6.6 \%$ of energy from fat, $76.8 \%$ from carbohydrate and $16.6 \%$ from protein) or a high-fat diet $(39.8 \%$ of energy from fat, $43.6 \%$ from carbohydrate and $16.6 \%$ from protein). The composition of these diets is given in Table 1 . Animals were killed after receiving standard chow or the high-fat diet for 35 weeks. Epididymal white adipose tissue (WATe) was removed and immediately frozen in liquid nitrogen for RNA preparation.

The generation of the Ilrn knockout mice by homologous recombination has been described previously [19]. These mice were backcrossed to the $\mathrm{C} 57 \mathrm{BL} / 6 \mathrm{~J}$ strain mice for
Table 1 Diet composition

Standard chow diet High-fat diet

\begin{tabular}{lrr}
\hline Crude protein $(\mathrm{N} \times 6.25)(\mathrm{g} / \mathrm{kg})$ & 180 & 180 \\
Crude fibre $(\mathrm{g} / \mathrm{kg})$ & 53 & 35 \\
Crude fat $(\mathrm{g} / \mathrm{kg})$ & 26 & 200 \\
Ash $(\mathrm{g} / \mathrm{kg})$ & 59 & 35 \\
Nitrogen-free extract $(\mathrm{g} / \mathrm{kg})$ & 615 & 470 \\
Metabolisable energy $(\mathrm{MJ} / \mathrm{kg})$ & 10.9 & 18.0 \\
\hline
\end{tabular}

more than ten generations and can be regarded as genetically homogeneous. Mice were housed individually from weaning, kept under specific pathogen-free conditions in an environmentally controlled clean room at the University Medical Centre (University of Geneva), and were allowed free access to standard chow diet. These mice were killed at 36-45 weeks of age, in the morning, $3 \mathrm{~h}$ after food removal. After killing, blood was collected in EDTA-coated tubes, placed on ice, centrifuged, and plasma was frozen. Plasma glucose was subsequently measured by the glucose oxidase method, and plasma insulin was assessed using a previously validated RIA [20].

For the clamp studies, 12-week-old OFA-SD wild-type male rats, weighing approximately $450 \mathrm{~g}$, were obtained from Charles River Laboratories (St Germain-sur-l'Arbresle, France) and housed individually at room temperature $\left(22^{\circ} \mathrm{C}\right)$, with a 12-h light-dark cycle and free access to water and food, before undergoing treatment with recombinant human IL-1Ra (rhIL-1Ra) (Kineret; Amgen Europe, Minervum, the Netherlands) and euglycaemic-hyperinsulinaemic clamps, as described below. Body weight and food intake, measured daily during the baseline period and rhIL$1 \mathrm{Ra}$ treatment, are given in Table 2.

RNA preparation and mRNA quantification Total RNA was prepared from $200 \mathrm{mg}$ of WATe using the Trizol reagent (Invitrogen, Basel, Switzerland) according to the manufacturer's instructions. Total RNA $(5 \mu \mathrm{g})$ was reversetranscribed using $800 \mathrm{U}$ Moloney murine leukaemia virus reverse transcriptase (Invitrogen) in the presence of RNA $\sin (0.3 \mathrm{U} / \mu \mathrm{l})$ (Promega Corp., Madison, WI, USA), random primers (oligo $\left.[\mathrm{dN}]_{6}, 7.5 \mu \mathrm{mol} / \mathrm{l}\right)$, dNTP $(1.2 \mathrm{mmol} / \mathrm{l})$ and dithiothreitol $(12 \mu \mathrm{mol} / \mathrm{l})$. Levels of transcripts of the genes encoding IL-1Ra (Illrn), IL-1 $\beta$ (Illb), IL-1RI (Illr1), IL-1RII (Illr2), TNF- $\alpha$ (Tnf), IL-6 (IlO), and of Arbp, a housekeeping gene, in the mouse were determined by quantitative real-time PCR using a LightCycler (Roche Diagnostics, Rotkreuz, Switzerland) with the DNA Master SYBR Green I or Fast Start DNA Master SYBR Green I (Roche Molecular Biochemicals, Rotkreuz, Switzerland) kits as appropriate [12]. Levels of each of the mRNAs were quantified in at least two independent LightCycler runs for each individual sample. The sequences of the primers used are shown in Table 3.

Measurement of insulin content of pancreas For measurement of insulin content, the whole pancreas was extracted in acid-ethanol before RIA, as previously described [20]. 
Table 2 Physiological and metabolic parameters of rhIL-1Ra-treated and control rats, before and during euglycaemic-hyperinsulinaemic clamps

\begin{tabular}{|c|c|c|c|c|c|c|}
\hline & $\begin{array}{l}\text { Body weight } \\
\text { (g) }\end{array}$ & $\begin{array}{l}\text { Food intake } \\
\text { (g/day) }\end{array}$ & $\begin{array}{l}\text { Glycaemia basal } \\
(\mathrm{mmol} / \mathrm{l})\end{array}$ & $\begin{array}{l}\text { Glycaemia after clamp } \\
(\mathrm{mmol} / \mathrm{l})\end{array}$ & $\begin{array}{l}\text { Insulinaemia basal } \\
(\mathrm{ng} / \mathrm{ml})\end{array}$ & $\begin{array}{l}\text { Insulinaemia after clamp } \\
(\mathrm{ng} / \mathrm{ml})\end{array}$ \\
\hline Control & $463 \pm 8.3$ & $28 \pm 0.7$ & $5.9 \pm 0.4$ & $7.6 \pm 0.1$ & $1.8 \pm 0.2$ & $8.5 \pm 0.6$ \\
\hline $\begin{array}{l}\text { rhIL-1Ra- } \\
\text { treated }\end{array}$ & $445 \pm 9.7$ & $28 \pm 2.0$ & $6.5 \pm 0.2$ & $7.4 \pm 0.1$ & $1.6 \pm 0.1$ & $7.2 \pm 0.5$ \\
\hline $\begin{array}{l}\text { Student's } \\
t \text { test }\end{array}$ & NS & NS & NS & NS & NS & NS \\
\hline
\end{tabular}

Values are means \pm SEM for seven to eight animals per group

rhIL-1Ra-rats were treated for 5 days with two daily s.c. injections of rhIL-1Ra $(6 \mathrm{mg} / \mathrm{kg})$; controls were injected s.c. with saline $(154 \mathrm{mmol} \mathrm{NaCl} / \mathrm{l})$

Histological examination of pancreas and immunohistological determination of insulin The pancreases of four mice per genotype were fixed in Bouin's solution, embedded in paraffin, and sections were stained with haematoxylin/eosin or processed for immunolabelling of insulin, as previously reported [21].

Euglycaemic-hyperinsulinaemic clamps Rats were treated for 5 days with either vehicle $(154 \mathrm{mmol} \mathrm{NaCl} / \mathrm{l})$ or rhIL$1 \mathrm{Ra}$ (s.c. injections of rhIL-1Ra two times per day, $6 \mathrm{mg}$ / $\mathrm{kg}$ ), with the last injection given $1 \mathrm{~h}$ before the start of the experiment. Before the euglycaemic-hyperinsulinaemic clamp studies, the rats were fasted for $15 \mathrm{~h}$ and anaesthetised with i.p. sodium pentobarbital $(55 \mathrm{mg} / \mathrm{kg})$. The clamps were performed using a constant infusion of $3 \mathrm{mU}$ insulin (Actrapid, Novo Nordisk, Bagsvaerd, Denmark) per min, and the glucose infusion rate needed to maintain normoglycaemia was determined. To measure total glucose utilisation (rate of glucose disappearance $[\mathrm{Rd}]$ ) and hepatic glucose production (rate of glucose appearance [Ra]), euglycaemic-hyperinsulinaemic clamps were performed with an infusion of $\mathrm{D}-\left[\mathrm{U}_{-}{ }^{14} \mathrm{C}\right]$ glucose $(1.850 \mathrm{MBq}$ per rat; Amersham, Aylesbury, UK), according to the method previously described [22]. At the end of the experiment, a bolus of 2-deoxy-D-[1- $\left.{ }^{3} \mathrm{H}\right]$ glucose $(1.110 \mathrm{MBq}$ per rat; Amersham) was injected intravenously to measure the in vivo insulin-stimulated glucose utilisation indices of specific tissues (muscle and adipose tissue), as previously described $[23,24]$. The tibialis muscle and WATe were frozen for further analysis.

Table 3 Primer sequences used for real-time RT-PCR
Analytical procedures relative to clamp studies The specific activities of 2-deoxy-D- $\left[1-{ }^{3} \mathrm{H}\right]$ glucose and D- $\left[\mathrm{U}_{-}{ }^{14} \mathrm{C}\right]$ glucose were determined in deproteinised blood samples, as previously reported $[23,24]$. Measurement of the tissue concentration of 2-deoxy-D- $\left[1-{ }^{3} \mathrm{H}\right]$ glucose 6 -phosphate allowed calculation of the in vivo glucose utilisation index in individual tissues and was expressed as $\mathrm{mg} \mathrm{min}^{-1} \mathrm{~kg}^{-1}$ tissue $[23,24]$. Plasma glucose was measured by the glucose oxidase method (Glucose Analyzer 2; Beckman Coulter, Fullerton, CA, USA), and plasma insulin was quantified using a previously described RIA [25].

Statistical analysis Results are expressed as means \pm SEM. The unpaired Student's $t$ test was used for comparison between groups of mice used in the high-fat diet experiments ( $n=9$ animals in each group), for comparison between $I l 1 \mathrm{rn}^{-1-}$ and wild-type mice used for glucose and insulin measurements ( $n=3-6$ animals in each group), and for comparison between groups of rats used in the clamp experiments ( $n=7-8$ animals in each group). These tests and linear regressions were performed with SYSTAT, version 10.01 software (SPSS, Chicago, IL, USA). A $p$ value of less than 0.05 was considered statistically significant.

\section{Results}

Effect of a high-fat diet on expression in the WAT of genes encoding proteins involved in the IL-1 signalling pathway Mice provided with a high-fat diet for 35 weeks had a higher body weight $(44.4 \pm 1.0 \mathrm{~g})$ than age-matched controls

\begin{tabular}{|c|c|c|}
\hline Gene targeted & Sense & Antisense \\
\hline Illrn & 5'-AAATCTGCTGGGGACCCTAC-3' & 5'-TCTTCTAGTTTGATATTTGGTCCTTG-3' \\
\hline$I l 1 b$ & 5'-TGTGAAATGCCACCTTTTGA-3' & 5'-GTGCTCATGTCCTCATCCTG-3' \\
\hline Illr1 & 5'-GAATGACCCTGGCTTGTGTT-3' & 5'-TGTGCTCTTCAGCCACATTC-3' \\
\hline Illr2 & 5'-GAGGGGCTACACCACCAGTA-3' & 5'-GGATTCGAGGCAACACATTT-3' \\
\hline $\operatorname{Tnf}$ & 5'-AGTTCTATGGCCCAGACCCT-3' & 5'-GTCTTTGAGATCCATGCCGT-3' \\
\hline Il6 & 5'-CACTTCACAAGTCGGAGCT-3' & 5'-TTCTGCAAGTGCATCATCG-3' \\
\hline$A r b p$ & 5'-CTGAACATCTCССССТСТC-3' & 5'-CGAATCCCATATCCTCATC-3' \\
\hline
\end{tabular}


fed a standard chow diet $(35.2 \pm 0.8 \mathrm{~g})$. No significant variation was found in glycaemia and insulinaemia between the two groups of animals (results not shown). Using quantitative RT-PCR, we examined the expression of the genes encoding the different components of the IL-1 signalling system in the adipose tissue of mice fed on the standard chow or the high-fat diet. As shown in Fig. 1a, the expression of genes encoding inhibitors of the IL-1 signalling pathway (IL-1Ra and IL-1RII) was upregulated in the WATe of mice with diet-induced obesity (fold increase: $6.4 \pm 1.2$ and $3.0 \pm 0.3$ for Il1 $\mathrm{rn}$ and $\mathrm{I} 11 \mathrm{r} 2 \mathrm{mRNA}$, respectively, $p<0.01$ ). In contrast, no significant change in the expression of genes for activators of the IL-1 signalling pathway (IL-1 $\beta$ and IL-1RI) was detected between the WATe of obese and lean animals. For comparison, we analysed the expression of genes encoding TNF- $\alpha$ and IL6 , previously shown to be expressed in adipose tissue.

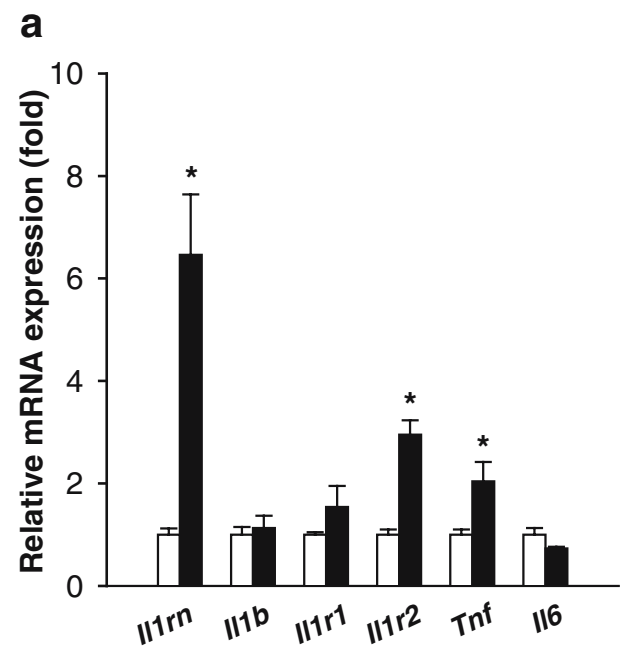

b

C
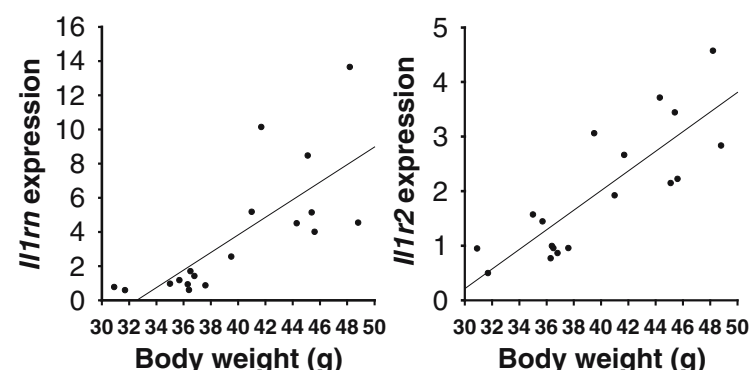

Fig. 1 Illrn and Il1r2 mRNA are overexpressed in adipose tissue after a high-fat diet and levels are correlated with body weight in mice. a Illrn, Illb, Illrl, Illr2, Tnf and Il6 mRNA levels in WATe isolated from mice fed a standard chow (open bars) or a high-fat (black bars) diet for 35 weeks. All mRNAs were quantified by realtime PCR as described in Materials and methods and normalised for the ribosomal Arbp mRNA levels. The bars represent means \pm SEM for nine animals ${ }^{*} p<0.05$ for comparison between standard chow and high-fat diet). b Correlation between Ill rn mRNA expression in WATe and body weight in mice after consumption of a standard chow or a high-fat diet for 35 weeks (linear regression analysis: $r^{2}=0.56, p<0.0001, n=18$ animals). c Correlation between Ill $r 2$ mRNA expression in WATe and body weight in mice after consumption of a standard chow or a high-fat diet for 35 weeks (linear regression analysis: $r^{2}=0.68, p<0.0001, n=18$ animals)

Indeed, when compared with those in lean mice, Tnf mRNA levels were increased by a factor of $2.0 \pm 0.4$ $(p<0.02)$ in the WATe of obese mice, while Il6 mRNA levels were not significantly altered (Fig. 1a). Interestingly, the expression of Illrn in WATe was strongly correlated with body weight $\left(r^{2}=0.56, p<0.0001\right)$ (Fig. 1b), as was the expression of Ill $r 2\left(r^{2}=0.68, p<0.0001\right)$ (Fig. 1c), while no correlations with Tnf or Il6 mRNA were found (results not shown).

Effect of Il1rn deletion (Illirn ${ }^{--}$) on circulating levels of glucose and insulin To study the role of endogenous Illrn in glucose homeostasis, we investigated serum glucose and insulin levels in Illrn-deficient mice. Ill $\mathrm{rn}^{-/}$mice had a reduced body weight compared with wild-type animals $(22.4 \pm 1.1$ vs $33.0 \pm 0.3 \mathrm{~g}$, respectively), as has been previously reported [18]. Postprandial glycaemia and insulinaemia (measured after $3 \mathrm{~h}$ of food deprivation) were $28 \pm 9 \%$ $(p<0.05)$ and $53 \pm 5 \%(p<0.002)$ lower in $I l 1 r^{-/}$mice than in wild-type mice, respectively (Fig. 2a,b). Hence, the insulin:glucose ratio was $31 \pm 6 \%$ lower in $\mathrm{Illrn}^{-/-}$mice than in wild-type mice $(p<0.005)$ (Fig. 2c), which is compatible with the increased insulin sensitivity in this group of animals.

Effect of Illrn deletion on pancreatic insulin content and islet morphology To determine if reduced insulin levels in Illrn-deficient mice were the result of a developmental beta cell defect, we measured insulin production by the pancreas. Although pancreatic weight normalised to body weight

Fig. 2 Illrn deletion $\left(I l 1 r n^{-1}\right)$ decreases serum glucose and insulin levels in mice. a Glucose levels in wild-type (open bar), Illrn ${ }^{+/-}$(grey bar) and Illrn (black bar) mice in the postprandial state, $3 \mathrm{~h}$ after food removal $\left({ }^{*} p<0.05\right.$ vs wild-type mice). b Insulin levels in the same groups of mice ${ }^{\dagger} p<0.002$ vs wild-type mice). c Insulin: glucose ratio in the same groups of mice $\left({ }^{\sharp} p<0.005\right.$ vs wild-type mice). In all panels, the bars represent means \pm SEM for three to six animals

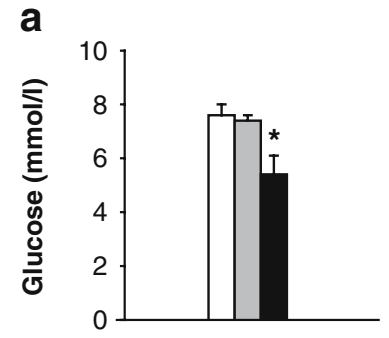

b

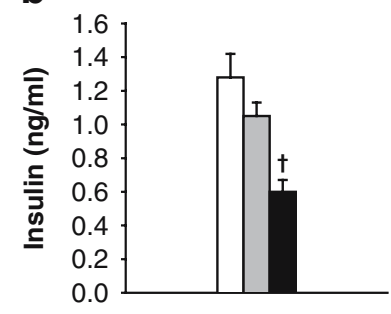

C

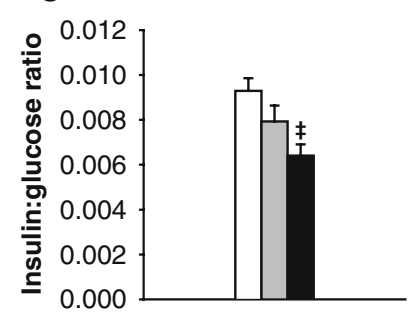


was $9 \pm 4 \%$ lower in $I l 1 \mathrm{rn}^{-/}$mice than in wild-type mice $(p<0.05)$ (Fig. 3a), the pancreatic insulin content was unchanged in Ill $\mathrm{rn}^{-1-}$ mice compared with either heterozygous or wild-type mice (Fig. 3b). Moreover, histological (Fig. 3c) and immunohistological (Fig. 3d) analysis of the pancreas revealed that the pancreatic islets of $111 \mathrm{rn}^{-/-}$mice were similar to those of wild-type mice in terms of morphology, size and insulin store.

Effect of IL-1Ra on glucose homeostasis Following our previous observation that circulating IL-1Ra levels are chronically and markedly elevated in obese patients [11], in the present study we assessed the effects of prolonged IL1 Ra excess on glucose homeostasis and insulin sensitivity in rodents. We injected rats s.c. twice daily for 5 days with either saline $(154 \mathrm{mmol} \mathrm{NaCl} / \mathrm{l})$ or rhIL-1 Ra $(6 \mathrm{mg} / \mathrm{kg})$. No significant difference in body weight or food intake was observed between rhIL-1Ra-treated and control rats (Table 2). Basal glycaemia and basal insulinaemia were also similar in a

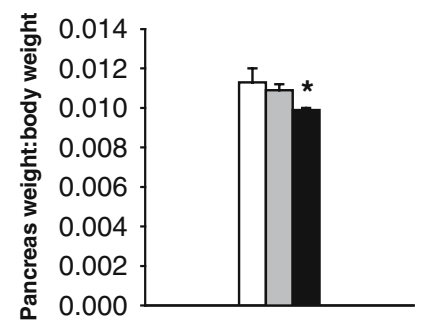

C

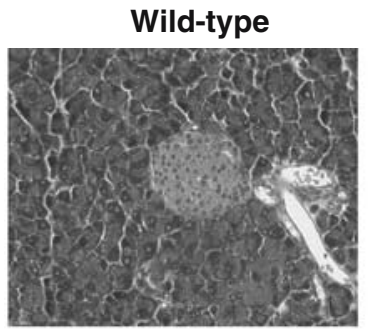

d

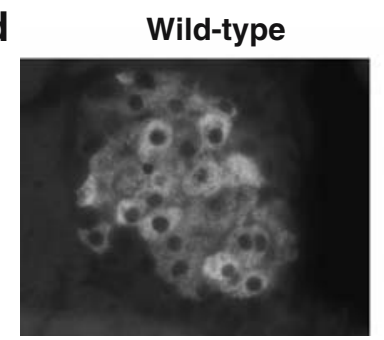

b
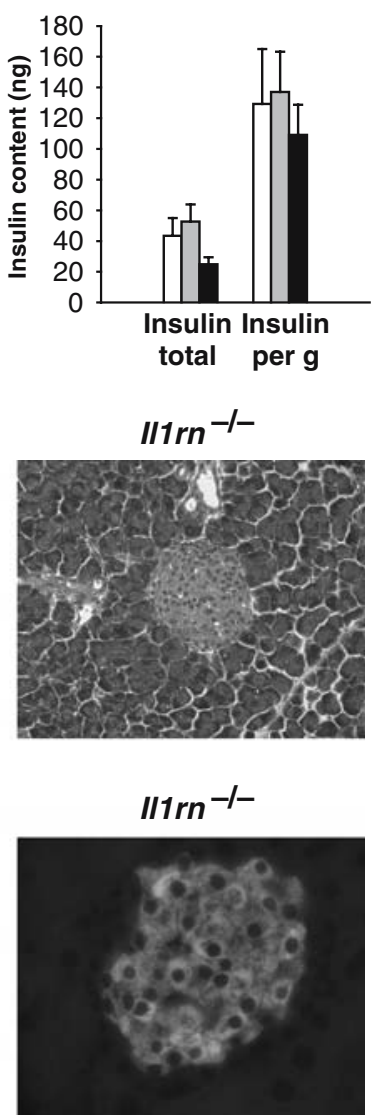

Fig. 3 Illrn deletion does not affect pancreatic insulin content or islet morphology in mice. a Ratio of pancreas weight:body weight in wild-type (open bar), Illrn ${ }^{+-}$(grey bar) and Il1rn ${ }^{-/-}$(black bar) mice $\left({ }^{*} p<0.05\right.$ compared with wild-type mice). b Insulin content per pancreas or per gram of pancreas in the same groups of mice. In both $\mathbf{a}$ and $\mathbf{b}$, the bars represent means \pm SEM for three to six animals. c Sections of pancreas from wild-type and $111 \mathrm{rn}^{-/}$mice stained with haematoxylin and eosin show similar islet appearance. d Immunostaining of insulin was comparable in beta cells from wild-type and Illrn ${ }^{-/-}$mice control rats and animals injected with rhIL-1Ra. However, the glucose infusion rate needed to maintain stable glycaemia during the euglycaemic-hyperinsulinaemic clamps was significantly decreased (by $24 \pm 4 \%, p<0.05$ ) in animals treated with rhIL-1Ra, while the glycaemia after the clamps was similar in both groups (Table 2 and Fig. 4a). Euglycaemic-hyperinsulinaemic clamps were then performed with $\left[{ }^{14} \mathrm{C}\right]$ glucose to determine $\mathrm{Rd}$ and $\mathrm{Ra}$. Compared with control animals, basal $\mathrm{Rd}$ was decreased $(p<0.05)$ by $21 \pm 8 \%$ in rhIL-1Ra-treated rats (Fig. 4b). Similarly, insulin-stimulated $\mathrm{Rd}$ was $32 \pm 8 \%$ lower $(p<0.05)$ in the treated group than in the control group (Fig. 4b). During the clamps, Ra was similarly suppressed by insulin in both groups (results not shown).

Taken together, these results indicate that excess IL-1Ra reduced the sensitivity of peripheral tissues to insulin.

Effect of IL-1Ra on tissue-specific glucose utilisation Tissue-specific glucose utilisation was measured by the labelled 2-deoxy-D- $\left[1-{ }^{3} \mathrm{H}\right]$ glucose technique at the end of euglycaemic-hyperinsulinaemic clamps. Insulin-stimulated glucose utilisation by the tibialis muscle (Fig. 4c) was decreased by $36 \pm 4 \%(p<0.05)$ in rats treated with rhIL-1Ra
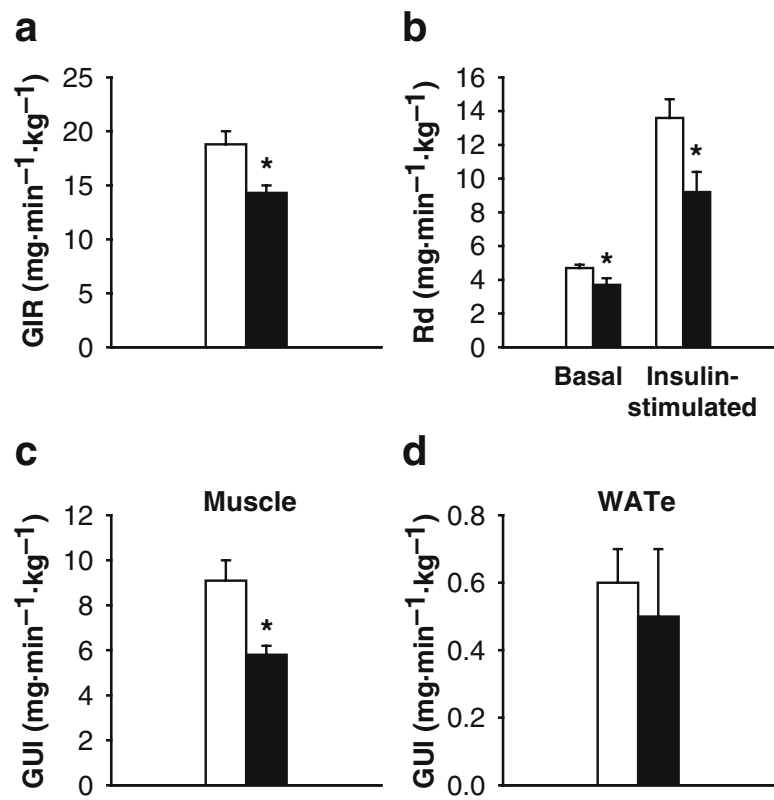

d

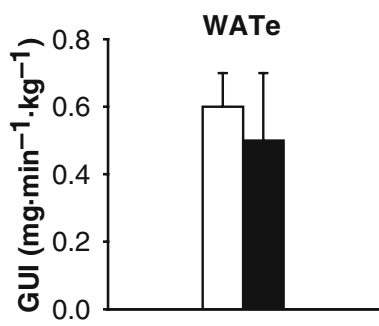

Fig. 4 IL-1Ra treatment decreases whole-body insulin sensitivity and tissue-specific glucose uptake in rats. a Glucose infusion rate (GIR) was measured at the end of euglycaemic-hyperinsulinaemic clamps in control (open bar) and rhIL-1Ra-treated (black bar) rats. Rats were treated for 5 days with two s.c. injections per day of rhIL1Ra $(6 \mathrm{mg} / \mathrm{kg})$. Control animals were injected with saline $(154 \mathrm{mmol} \mathrm{NaCl} / \mathrm{l}) .{ }^{*} p<0.05$ vs control rats. b Rd was determined before and at the end of euglycaemic-hyperinsulinaemic clamps in the same groups of rats, using $\mathrm{D}-\left[\mathrm{U}_{-}{ }^{14} \mathrm{C}\right]$ glucose as described in Materials and methods. ${ }^{*} p<0.05$ vs control rats. c The glucose utilisation index (GUI) was determined at the end of euglycaemichyperinsulinaemic clamps in the tibialis muscle of the same groups of rats, using 2-deoxy-D- $\left[1-{ }^{3} \mathrm{H}\right]$ glucose as described in Materials and methods. ${ }^{*} p<0.05$ vs control rats. d The glucose utilisation index was also determined at the end of euglycaemic-hyperinsulinaemic clamps in WATe of the same groups of rats. In all panels, the bars represent means \pm SEM for seven to eight animals 
compared with that in controls. A trend towards a decrease in utilisation was also observed in the quadriceps and gastrocnemius muscles (results not shown). In contrast, insulin-stimulated glucose utilisation was unchanged in WATe (Fig. 4d) and in the inguinal and perirenal WAT depots (results not shown). Hence, these results demonstrate a muscle-specific decrease in insulin sensitivity of rats treated with rhIL-1Ra.

\section{Discussion}

In this study we have shown that diet-induced obesity enhances the expression of Illrn in mouse WAT. This observation is in line with our previous finding of a nearly 40-fold increase in levels of Illrn mRNA in the WAT of $o b$ / $o b$ mice with long-standing severe obesity [12] and a sevenfold increase in serum levels of IL-1Ra in obese humans [11]. Interestingly, the increase in Il1rn mRNA observed in WAT during diet-induced obesity is associated with a threefold increase in Illr2 mRNA. This suggests that IL-1 signalling is downregulated in obesity, not only systemically, but also locally in WAT. Since IL-1 is known to enhance insulin action under certain conditions [26, 27], it is possible that the decreased signalling of IL-1 contributes to obesity-associated insulin resistance. As previously reported [1], we confirmed the increased expression of Tnf in the WAT from mice with diet-induced obesity, while no alteration of Il6 expression was found. This is in contrast to the previously reported overexpression of Il6 in the WAT of genetically obese $o b / o b$ mice [28], which, however, have a much more pronounced increase in fat mass than our model of diet-induced obesity.

Since we reported in our earlier human studies that IL$1 \mathrm{Ra}$ serum levels are better correlated with insulin sensitivity than with BMI [11], we used rodent models of IL-1 Ra deficiency and excess to examine a possible causal relationship among IL-1, IL-1Ra and glucose homeostasis. $\mathrm{ll}_{\mathrm{rn}}{ }^{-/}$ mice showed a decrease in serum insulin levels, as well as a decreased insulin:glucose ratio, supporting the enhanced insulin sensitivity previously reported in these animals [18]. However, since IL-1 was previously shown to be toxic to islets $[29,30]$, we examined whether there was any alteration in pancreatic insulin content and/or islet structure in Illrn knockout mice. Since no obvious pancreatic or islet anomaly was found, it is likely that the normoglycaemichypoinsulinaemic status of the knockout animals reflects an increase in peripheral insulin sensitivity, as a result of a chronic unopposed IL-1 action.

The hypothesis that IL-1Ra is an insulin-desensitising factor was substantiated by the treatment of normal rats with rhIL-1Ra, which resulted in a decreased rate of glucose utilisation in both the basal and insulin-stimulated state during euglycaemic-hyperinsulinaemic clamps. The insulin resistance of rhIL-1Ra-treated rats was unrelated to hepatic glucose production, which was normally suppressed by insulin in both the controls and the rhIL-1Ra-treated animals. The finding that IL-1Ra leads to insulin resistance in rats is in keeping with our earlier clinical observation that serum IL-1Ra levels are positively correlated with insulin resistance in obese humans $\left(r^{2}=0.58\right)$ [11]. Interestingly, the glucose utilisation index of insulin-sensitive tissues was selectively decreased in the skeletal muscle of rhIL-1Ratreated rats. The reason for this tissue-specific effect remains to be elucidated. However, the observed reduction in global Rd is well explained by the reduction in 2-deoxy-D$\left[1-{ }^{3} \mathrm{H}\right]$ glucose uptake into muscle cells. These observations are in agreement with previous pharmacological studies demonstrating that the chronic administration of IL-1 to rodents induces hypoglycaemia, probably due to increased glucose transport into tissues to increase the energy supply to tissues during high metabolic demands [31-33]. Further investigations are required to understand the crosstalk between IL-1 and insulin signalling at the cellular and molecular level, and to determine whether phosphatidylinositol-3-kinase, which participates in IL-1 and insulin signalling, is implicated. While the principal aim of this study was to examine the metabolic impact of excess IL$1 \mathrm{Ra}$ as it is observed in human obesity, clamp studies in IL1Ra-deficient mice would be useful to validate these findings.

In conclusion, we have shown that the expressions of $I l 1 r n$ and $I l 1 r 2$, the decoy receptor, are strongly upregulated in WATe after high-fat feeding, and the extent of upregulation is proportional to body weight. Moreover, excess IL-1Ra leads to impaired glucose uptake in skeletal muscle. These results support the hypothesis that IL-1Ra provides a functional link between obesity and insulin resistance.

Acknowledgements This work was supported by Swiss National Science Foundation (SNSF) Grants 3200B0-103618 to C. A. Meier and $3100 \mathrm{~A} 0-105889 / 1$ to F. Rohner-Jeanrenaud. The work of P. Meda was supported by grants from the SNSF (310000-109402), the JDRF (1-2005-46), the EU (QLRT-2001-01777) and the NIH (RO1 DK-63443). This study was part of the Geneva programme for metabolic disorders (GeMet). The authors confirm the absence of any conflict of interest.

\section{References}

1. Hotamisligil GS, Shargill NS, Spiegelman BM (1993) Adipose expression of tumor necrosis factor-alpha: direct role in obesitylinked insulin resistance. Science 259:87-91

2. Hotamisligil GS, Arner P, Caro JF et al (1995) Increased adipose tissue expression of tumor necrosis factor-alpha in human obesity and insulin resistance. J Clin Invest 95:2409 2415

3. Kern PA, Saghizadeh M, Ong JM et al (1995) The expression of tumor necrosis factor in human adipose tissue. Regulation by obesity, weight loss, and relationship to lipoprotein lipase. J Clin Invest 95:2111-2119

4. Pincelli AI, Brunani A, Scacchi M et al (2001) The serum concentration of tumor necrosis factor alpha is not an index of growth-hormone- or obesity-induced insulin resistance. Horm Res 55:57-64

5. Ronnemaa T, Pulkki K, Kaprio J (2000) Serum soluble tumor necrosis factor-alpha receptor 2 is elevated in obesity but is not related to insulin sensitivity: a study in identical twins discordant for obesity. J Clin Endocrinol Metab 85:2728-2732

6. Mohamed-Ali V, Goodrick S, Rawesh A et al (1997) Subcutaneous adipose tissue releases interleukin-6, but not tumor necrosis factor-alpha, in vivo. J Clin Endocrinol Metab 82: 4196-4200 
7. Fried SK, Bunkin DA, Greenberg AS (1998) Omental and subcutaneous adipose tissues of obese subjects release interleukin-6: depot difference and regulation by glucocorticoid. J Clin Endocrinol Metab 83:847-850

8. Vgontzas AN, Papanicolaou DA, Bixler EO et al (1997) Elevation of plasma cytokines in disorders of excessive daytime sleepiness: role of sleep disturbance and obesity. J Clin Endocrinol Metab 82:1313-1316

9. Roytblat L, Rachinsky M, Fisher A et al (2000) Raised interleukin-6 levels in obese patients. Obes Res 8:673-675

10. Bastard JP, Jardel C, Bruckert E et al (2000) Elevated levels of interleukin 6 are reduced in serum and subcutaneous adipose tissue of obese women after weight loss. J Clin Endocrinol Metab 85:3338-3342

11. Meier CA, Bobbioni E, Gabay C et al (2002) IL-1 receptor antagonist serum levels are increased in human obesity: a possible link to the resistance to leptin? J Clin Endocrinol Metab 87:1184-1188

12. Juge-Aubry CE, Somm E, Giusti V et al (2003) Adipose tissue is a major source of interleukin-1 receptor antagonist: upregulation in obesity and inflammation. Diabetes 52:1104-1110

13. Arend WP (1990) Interleukin-1 receptor antagonist: discovery, structure and properties. Prog Growth Factor Res 2:193-205

14. Neumann D, Kollewe C, Martin MU et al (2000) The membrane form of the type II IL-1 receptor accounts for inhibitory function. J Immunol 165:3350-3357

15. Luheshi GN, Gardner JD, Rushforth DA et al (1999) Leptin actions on food intake and body temperature are mediated by IL-1. Proc Natl Acad Sci USA 96:7047-7052

16. Gregoire F, De Broux N, Hauser N et al (1992) Interferongamma and interleukin-1 beta inhibit adipoconversion in cultured rodent preadipocytes. J Cell Physiol 151:300-309

17. Suzawa M, Takada I, Yanagisawa J et al (2003) Cytokines suppress adipogenesis and PPAR-gamma function through the TAK1/TAB1/NIK cascade. Nat Cell Biol 5:224-230

18. Matsuki T, Horai R, Sudo K et al (2003) IL-1 plays an important role in lipid metabolism by regulating insulin levels under physiological conditions. J Exp Med 198:877-888

19. Nicklin MJ, Hughes DE, Barton JL et al (2000) Arterial inflammation in mice lacking the interleukin 1 receptor antagonist gene. J Exp Med 191:303-312

20. Meda P, Bosco D, Chanson M et al (1990) Rapid and reversible secretion changes during uncoupling of rat insulin-producing cells. J Clin Invest 86:759-768
21. Charollais A, Gjinovci A, Huarte J et al (2000) Junctional communication of pancreatic beta cells contributes to the control of insulin secretion and glucose tolerance. J Clin Invest 106:235-243

22. Terrettaz J, Assimacopoulos-Jeannet F, Jeanrenaud B (1986) Severe hepatic and peripheral insulin resistance as evidenced by euglycemic clamps in genetically obese fa/fa rats. Endocrinology 118:674-678

23. Cusin I, Terrettaz J, Rohner-Jeanrenaud F et al (1990) Metabolic consequences of hyperinsulinaemia imposed on normal rats on glucose handling by white adipose tissue, muscles and liver. Biochem J 267:99-103

24. Vettor R, Zarjevski N, Cusin I et al (1994) Induction and reversibility of an obesity syndrome by intracerebroventricular neuropeptide $\mathrm{Y}$ administration to normal rats. Diabetologia 37:1202-1208

25. Herbert V, Lau KS, Gottlieb CW et al (1965) Coated charcoal immunoassay of insulin. J Clin Endocrinol Metab 25:13751384

26. Del Rey A, Besedovsky H (1987) Interleukin 1 affects glucose homeostasis. Am J Physiol 253:R794-R798

27. Del Rey A, Monge-Arditi G, Besedovsky HO (1998) Centra and peripheral mechanisms contribute to the hypoglycemia induced by interleukin-1. Ann N Y Acad Sci 840:153-161

28. Harkins JM, Moustaid-Moussa N, Chung YJ et al (2004) Expression of interleukin-6 is greater in preadipocytes than in adipocytes of 3T3-L1 cells and C57BL/6J and ob/ob mice. J Nutr 134:2673-2677

29. Maedler K, Sergeev P, Ris F et al (2002) Glucose-induced beta cell production of IL-1beta contributes to glucotoxicity in human pancreatic islets. J Clin Invest 110:851-860

30. Jhala U, Baly DL (1994) Effect of chronic IL-1 beta infusion on glucose homeostasis and pancreatic insulin secretion. Life Sci $54: 413-422$

31. Besedovsky HO, del Rey A (1989) Interleukin-1 and glucose homeostasis: an example of the biological relevance of immune-neuroendocrine interactions. Horm Res 31:94-99

32. Del Rey A, Besedovsky H (1989) Antidiabetic effects of interleukin 1. Proc Natl Acad Sci USA 86:5943-5947

33. Lang CH, Dobrescu C (1989) Interleukin-1 induced increases in glucose utilization are insulin mediated. Life Sci 45:21272134 